\title{
Addition of Eucalyptus sp wood to urban wood waste as a strategy for energetic use
}

\author{
Adição da madeira de Eucalyptus sp aos resíduos madeireiros urbanos como \\ estratégia para a geração de energia
}

\author{
Ananias Francisco Dias Júnior ${ }^{1}$ (D), Helena Arthuso² (D), Artur Queiroz Lana ${ }^{2}$ (D), \\ Carlos Rogério Andrade ${ }^{3}$ (), José Otávio Brito ${ }^{2}$ (D), Geraldo Bortoletto Júnior ${ }^{2}$ (D) \\ ${ }^{1}$ Universidade Federal do Espírito Santo - UFES, Jerônimo Monteiro, ES, Brasil \\ 2Escola Superior de Agricultura "Luiz de Queiroz" - ESALQ, Universidade de São Paulo - USP, Piracicaba, SP, Brasil \\ ${ }^{3}$ Universidade Federal de Jataí - UFJ, Jataí, GO, Brasil
}

\begin{abstract}
How to cite: Dias Júnior, A. F., Arthuso, H., Lana, A. Q., Andrade, C. R., Brito, J. O., \& Bortoletto Júnior, G. (2021). Addition of Eucalyptus sp wood to urban wood waste as strategy for energetic use. Scientia Forestalis, 49(129), e3230. https://doi.org/10.18671/scifor.v49n129.05
\end{abstract}

\begin{abstract}
This study analyzed the effect of adding Eucalyptus sp. wood to urban wood waste (UWW) as a strategy for improving the material for energy use. The UWW was collected at a recycling plant in the town of Piracicaba and the wood of Eucalyptus sp. came from a seven years old plantation. Five proportions (\%) of WWU and eucalyptus wood were tested: $\mathrm{T} 1=100 / 0, \mathrm{~T} 2=75 / 25, \mathrm{~T} 3=50 / 50, \mathrm{~T} 4=25 / 75$ and T5 = 0/100. Physical, chemical and immediate properties were evaluated. In addition the mineral contaminants content and the presence of heavy metals in the wood and in ashes of T1 and T5 were determined. The results showed lignin, fixed carbon and ash content higher in treatments with greater amounts of UWW. Heavy metals were detected in both treatments. T4 treatment stood out as the best strategy to the use of UWW, related to its energy potential combined with low ash content and lower contamination of minerals.
\end{abstract}

Keywords: Biomass and energy; Wood waste use; Eucalyptus wood; Heavy metals.

\section{Resumo}

Este trabalho analisou o efeito da adição de madeira de Eucalyptus sp aos resíduos madeireiros de origem urbana (RMOU) como estratégia para geração de energia. Os RMOU foram coletados em uma Usina de Reciclagem no município de Piracicaba, SP e a madeira de Eucalyptus sp foi obtida a partir de um plantio de sete anos de idade. Foram analisadas cinco proporções (\%) de RMOU e madeira de Eucalyptus sp., sendo $\mathrm{T} 1=100 / 0, \mathrm{~T} 2=75 / 25, \mathrm{~T} 3=50 / 50, \mathrm{~T} 4=25 / 75$ e T5 =0/100. Analisaram-se as características físicas, químicas e composição imediata. Determinaram-se ainda, os teores de contaminantes minerais e a ocorrência de metais pesados nos materiais in natura e nas cinzas dos tratamentos T1 e T5. Os resultados evidenciaram teores de lignina, de carbono fixo e de cinzas mais elevados nos tratamentos com maiores proporções de RMOU. Foram detectados metais pesados em dois tratamentos. O tratamento T4 destacou-se como melhor estratégia para utilização de RMOU, visto seu potencial energético, aliado a baixos teores de cinzas e a menor taxa de contaminação por minerais.

Palavras-chave: Biomassa e energia; Aproveitamento de resíduos madeireiro; Madeira de Eucalyptus; Metais pesados.

Financial support: Instituto de Pesquisas e Estudos Florestais - IPEF (no number).

Conflict of interest: Nothing to declare.

Corresponding author: ananias.dias@ufes.br

Received: 19 December 2018.

Accepted: 3 April 2020.

Editor: Paulo Henrique Müller Silva.

(c) (i) This is an Open Access article distributed under the terms of the Creative Commons Attribution License, which permits unrestricted use,

cc) distribution, and reproduction in any medium, provided the original work is properly cited. 


\section{INTRODUCTION}

The increase in generation of urban wood wastes in Brazil and their improper disposal have aroused concerns on environmental problems that they may cause. In most cases, these residues are allocated without any prior treatment and the common destinations are construction and demolition landfills, municipal solid waste landfills, specific landfill for inert materials, recycling stations and illegal deposition (Brasil, 2009). It is estimated that the construction sector and the urban areas (urban pruning) together are responsible for the generation of 2.85 million tons of wooden waste in Brazil, corresponding to approximately $11 \%$ of the national total (Wiecheteck, 2009). In general, urban solid wastes are represented mainly by paper, glass, wood, plastics and organic materials. Among the different types, one of the main ones is wooden waste, consisting mainly of rest of pallets, construction timbers and other woods mixed with municipal solid waste (Atkins \& Donovan, 1996). Often other materials are found adhered to the wood waste such as additives, preservatives, ink, resins, cement, mortar, metallic materials (nails, hinges, etc.), paper, cardboard, waxes and adhesives (Scotland, 2004; Wiecheteck, 2009). Aside from the mentioned contaminants, there is the possibility of the contamination of urban wood waste (UWW) by hazardous substances such as heavy metals coming from preservative treatments of wood (Bouslamti et al., 2012).

Among the possibilities of reuse of the wood residues the energy generation stands out, since it has a renewable potential as biomass. However, greater knowledge of the material is needed given the possibility of its contamination, which requires characterization studies for an appropriate destination (Krook et al., 2006). The energy features of UWW vary wildly and often are unfavorable for its use, mainly because of the diversity of materials in its composition. In addition, pollution problems such as contamination of soil, atmosphere and groundwater may hinder the recycling of materials and can compromise the use of byproducts (Reijnders, 2000; Kovacs et al., 2016). The UWW presents a potential feedstock for energetic use, because they are easy to obtain and have virtually no cost. The use for this purpose can represent a minimization of environmental problems which, with a proper destination also creates a chain use for these products, generating new jobs, new revenues and increased tax collection, with positive environmental, social and economic results (Wiecheteck, 2009).

According to Reis (2015) studies for better understanding the energy features of UWW can guide them to promising uses, e.g. for electricity generation. Currently, however, this application has been restricted but should gradually increase over time and may become an important and complementary source of energy instead of hydroelectricity and fossil fuel from thermal power plants. In Sweden, for example, solid wastes are already responsible for generating almost $60 \%$ of the electricity used in heating systems of urban buildings (Krook et al., 2006). The uses of UWW in boiler furnaces for steam generation, distillation furnaces, forging and potteries, also are potential alternatives and are used (Dias Júnior et al., 2014). Brazil, in spite of generating large amounts of wood residues, stands out in the cultivation of eucalyptus, the most planted forest tree. Eucalypt species occupy approximately 5.7 million hectares (Indústria Brasileira de Árvores, 2017). The fast growth of this renewable biomass associated with its multiple use with emphasis on the energy destination, given that wood provided 8\% of the domestic energy supply in 2016 (Brasil, 2017), makes eucalyptus wood attractive to be added to other materials aiming at improving the characteristics of the mixture. In addition, it is a widely studied genus with regard to characterization and properties.

Hence, it has been hypothesized that the addition of homogeneous material, as from a single species, to UWW will provide improvement in the characteristics for thermal purpose. Thus, this research aimed to study the characteristics of UWW and the addition of Eucalyptus spp. wood in different proportions. Therefore, the physical, chemical and immediate features, mineral contaminants and heavy metals contents were analyzed. 


\section{MATERIALS AND METHODS}

The collection site was a construction waste recycling plant that additionally receives wood from other sectors collected by the dump services of the town of Piracicaba, SP/Brazil (Figure 1). The sampling was done according to the Brazilian standard NBR 10.007 (Associação Brasileira de Normas Técnicas, 2004). The wood of Eucalyptus (hybrid of Eucalyptus grandis $x$ Eucalyptus urophylla) came from a seven years old plantation.

In the plant the collected UWW material passed through a conveyor belt containing a magnetic plate for metal removal. Then, the materials were chipped and homogenized in a $30 \mathrm{~mm}$ sieve. The UWW chips sieved at $30 \mathrm{~mm}$ (approximately $340 \mathrm{~kg}$ ) were taken to the Laboratory of Chemistry, Pulp and Energy - LQCE ESALQ/USP, where the analyzes were carried out. For better description of the studied material, UWW chips were manually separated and identified in $56 \%$ of solid wood and $44 \%$ reconstituted wood panels. The logs of Eucalyptus sp. were also chipped and sieved at $30 \mathrm{~mm}$. The materials remained in the oven at $103 \pm 2^{\circ} \mathrm{C}$ for drying to constant weight and five treatments were defined:

- T1: $100 \%$ chips of UWW.

- T2: $75 \%$ chips of UWW and $25 \%$ of Eucalyptus sp.

- T3: $50 \%$ chips of UWW and 50\% of Eucalyptus sp.

- T4: $25 \%$ chips of UWW and $75 \%$ of Eucalyptus sp.

- T5: $100 \%$ chips of Eucalyptus sp. wood.

\subsection{Assays}

The extractive content was determined according to the standard Tappi T-12 05-75 (Technical Association of the Pulp and Paper Industry, 1975), and the lignin content was defined following the Tappi standard 222 05-74 (Technical Association of the Pulp and Paper Industry, 1974). The holocellulose content was obtained indirectly, being given by the total minus the contents of lignin and ashes. The immediate analysis was done to determine the volatile matter, the ash and the fixed carbon contents, according to the standard NBR 8112 (Associação Brasileira de Normas Técnicas, 1986). The higher heating value was determined using a digital calorimeter Ika C-2000, according to NBR 8633 (Associação Brasileira de Normas Técnicas, 1984) and the lower heating value; that is the result of combustion under constant pressure in the open air discounting the condensation of water formed, was calculated according to Brand (2010), using the Equation 1 below.

$$
\mathrm{LHV}=\mathrm{HHV}-600 \frac{9 \mathrm{H}}{100}
$$

Where: $\mathrm{LHV}=$ lower heating value $\left(\mathrm{MJ} \mathrm{kg}^{-1}\right) ; \mathrm{HHV}=$ higher Heating Value $\left(\mathrm{MJ} \mathrm{kg}^{-1}\right) ; \mathrm{H}=$ theoretical hydrogen content: assumed as $6 \%$.

To ascertain the mineral contaminant content the protocol described by Brito \& Ceribelli (2012) was adapted. This analysis assists in the estimation of minerals coming from external contamination, non-woody components. A composite sample for each treatment was made, and ten grams sieved between 20 and 40, placed in a beaker of $250 \mathrm{ml}$, previously filled with $200 \mathrm{ml}$ of distilled water was used. The suspension was stirred for a minute and left to rest for five minutes. In a next step, the supernatant material in solution was collected and dried till constant weight. By this methodology it is accepted that the supernatant wood is free of contaminating minerals due to their decantation.

The material ashes, free from external contaminants, were obtained according to the standard NBR 8112 (Associação Brasileira de Normas Técnicas, 1986). All procedures were done in three replicates. The contamination rate was determined using the Equation 2 (Dias Júnior et al., 2017). 
$\mathrm{CR}(\%)=\frac{\mathrm{ASt}-\mathrm{ASm}}{\mathrm{ASt}} \times 100$

Where: $\mathrm{CR}=$ contamination rate; $\mathrm{ASt}=$ total ashes content (wood ash + contaminant ashes) (\%); ASm = material ash content (free of external contaminant - \%).

The analysis of the heavy metals was performed by plasma mass spectrometry technique (ICP-MS) following the standard EPA (U.S. Environmental Protection Agency, 2000, 2007). This method proposed to determine the elements: Arsenic (As), Lead (Pb), Mercury (Hg), Chromium (Cr), Copper (Cu), Cadmium (Cd), Zinc (Zn) and Iron (Fe). This analysis was conducted in the raw materials as collected (minced and sifted wood) and in the ashes of treatments T1 (100\% UWW) and T5 (100\% Eucalyptus sp.). This procedure was adopted due to the intermediate treatments consisting of a blend of these two extremes, probably showing intermediate characteristics in accordance to the percentage of each material.

\subsection{Data analysis}

The data were tested for their variances (Levene) and normality (Shapiro-Wilk) test before an analysis of variance was performed. The ANOVA was done in a completely randomized design, composed of five treatments (described in Section 2.1) and five replications. When the hypothesis $H O$ (equal population means) was rejected, the Scott-Knott test for multiple comparison of mean values of treatments was applied. The analyses were conducted at a $95 \%$ confidence interval.

Beyond the multivariate analyses of principal component was performed in order to inform the proximity between the treatments. Thus, only the average of each variable except for the chemicals heavy metals was considered; where the analysis was conducted based on the data correlation matrix. For better accuracy, the data were first standardized with mean 0 and variance 1 (Mingoti, 2005). Then, it was possible to determine the scores of the principal components of interest for classification and clusters formation to the analyzed treatments. The principal components analysis (PCA), allows to indirectly identify the best compositions for the energetic use of better efficiency. By PCA it is possible to explain the variance and covariance structure of a random vector (composed of random p-variables) by constructing linear combinations of the original variables, with $p$ original variables and $p$ principal components obtained. In general, by the use of PCA, it is desired to decrease the number of variables to be evaluated and to facilitate the interpretation of the linear combinations constructed. The obtaining of the main components involves the decomposition of the covariance matrix of the random vector of interest. Once the main components were determined, their scores (values) were calculated for each sample element. This method allows to determine, from the characteristics of the treatments, subsets in which each unit belongs only to one subset, and that the units grouped in the same subset are similar to each other and different from the units of other subsets (Sgarbossa et al., 2015; Strandberg et al., 2017).

\section{RESULTS AND DISCUSSION}

\subsection{Chemical composition and immediate}

Table 1 show the difference between treatments of basic chemical components and each result of immediate analysis.

The addition of Eucalyptus sp. did not influence the extractive content since only the treatment composed exclusively of eucalyptus wood (T5) showed lower content. It is possible that the solvents used in the assay to remove the extractives also removed other type of components adhered to wood, such as paints, varnishes and adhesives, that can have increased the extractive content in treatments containing UWW. The higher amount of extractives in the treatments containing UWW may also be explained by the fact that in their composition are reconstituted materials (panels, boards, etc.); often produced from 
coniferous wood (Iwakiri et al., 2005), which usually have a higher amount of extractives than hardwood, as observed by Yamamoto et al. (2014).

Table 1. Chemical composition and immediate.

\begin{tabular}{ccccccc}
\hline Treatment & EX & LIG & HOL & VM & FC & AS \\
\hline T1 & $17.84^{\mathrm{a}}{ }_{(3.13)}$ & $28.23^{\mathrm{a}}{ }_{(9.50)}$ & $53.93^{\mathrm{c}}{ }_{(5.62)}$ & $83.32^{\mathrm{b}}{ }_{(8.97)}$ & $18.54^{\mathrm{a}}{ }_{(11.27)}$ & $1.36^{\mathrm{a}}(7.65)$ \\
T2 & $17.87^{\mathrm{a}}{ }_{(4.40)}$ & $28.42^{\mathrm{a}}{ }_{(2.92)}$ & $55.70^{\mathrm{c}}{ }_{(2.39)}$ & $81.32^{\mathrm{b}}{ }_{(2.56)}$ & $17.58^{\mathrm{a}}{ }_{(12.44)}$ & $1.10^{\mathrm{a}}{ }_{(9.13)}$ \\
T3 & $17.20^{\mathrm{a}}{ }_{(6.76)}$ & $24.85^{\mathrm{b}}{ }_{(0.79)}$ & $61.59^{\mathrm{b}}{ }_{(8.13)}$ & $83.37^{\mathrm{b}}{ }_{(2.79)}$ & $16.06^{\mathrm{b}}{ }_{(14.15)}$ & $0.56^{\mathrm{b}}{ }_{(10.79)}$ \\
T4 & $17.48^{\mathrm{a}}{ }_{(12.57)}$ & $22.95^{\mathrm{b}}{ }_{(7.34)}$ & $59.72^{\mathrm{b}}{ }_{(5.05)}$ & $82.68^{\mathrm{b}}{ }_{(0.42)}$ & $16.90^{\mathrm{b}}{ }_{(2.88)}$ & $0.42^{\mathrm{b}}{ }_{(42.87)}$ \\
T5 & $7.75^{\mathrm{b}}{ }_{(26.84)}$ & $23.18^{\mathrm{b}}{ }_{(6.12)}$ & $69.07^{\mathrm{a}}{ }_{(10.33)}$ & $86.08^{\mathrm{a}}{ }_{(3.92)}$ & $14.20^{\mathrm{c}}{ }_{(16.88)}$ & $0.29^{\mathrm{b}}{ }_{(1.75)}$ \\
\hline
\end{tabular}

Where: $\mathrm{EX}=$ extractive content (\%); LIG = lignin content (\%); $\mathrm{HOL}=$ holocellulose content (\%); VM = volatile matter content (\%); FC = fixed carbon content (\%); AS = ash content (\%). Averages followed by the same letters do not differ in the same column by test Scott-Knott at $5 \%$ of significance ( $p$ value $>0.05$ ). Values between brackets are the coefficient of variation.

The treatments having greater amount of UWW (T1 and T2) showed the highest levels of lignin content. It is assumed that this behavior may be related mainly to the presence of wood panels, originally produced with wood of Pinus spp; according to Carvalho et al. (2009) softwoods have higher lignin content than hardwoods. In addition, wood panels are produced largely with mixed young trees, coming from short-rotation plantations, where the percentage of juvenile wood is higher than mature wood (Pecho et al., 2004) and commonly have a higher lignin content (Rowell et al., 2000). Another possibility is that the resins, glues and paints usually present in these panels, could be diluted in acidic solutions and thus might have been mistaken as lignin. The holocellulose content showed the opposite behavior to lignin: it was lower in $\mathrm{T} 1$ and $\mathrm{T} 2$, intermediate in $\mathrm{T} 3$ and $\mathrm{T} 4$, and higher in $\mathrm{T} 5$. The holocellulose, extractives, lignin and minerals vary, among other factors, according to the species and age of the wood; these chemical components are related to the energy potential of the material, when they are correlated to the higher heating value (Quirino et al., 2004). This is also corroborated by the fact that coniferous wood, most used for the manufacture of wooden panels, have the lowest content of holocellulose (Yamamoto et al., 2014), as presented in T1 and T2.

The immediate analysis determines the volatile matter, ash and fixed carbon contents; important in the characterization of fuels and correct indication for use. T5 showed the higher content of volatile matter. The panels and other reconstituted materials present in the UWW are previously pressed and dried (particles and fibers) under high temperature, partially removing some of the more volatile components. This fact is possibly associated with lower VM values obtained for treatments with greater amount of UWW in their composition, since the heating, even if moderate, removes some more volatile components from the wood (Aquino et al., 2005).

$\mathrm{T} 1$ and $\mathrm{T} 2$ showed higher, T5 lower, and T3 and T4 intermediate fixed carbon content. There was an increasing trend of fixed carbon content with the increase of the percentage of UWW in the compositions. None of the treatments was heat treated for carbon concentration, it is believed that this observation emphasizes the hypothesis that UWW have in their composition greater quantities of wood from conifers, since they have lager carbon content than the hardwoods. Fuels with high carbon content burn more slowly, resulting in longer residence time in the combustion and requires less refueling (Dias Júnior et al., 2014).

Regarding the ashes, T1 and T2 presented the highest levels. As found for the fixed carbon content; there is an increasing trend with an increase in the proportion of UWW. Ashes are inorganic compounds (minerals), which are used in paints, adhesives and varnishes; they are usually found in reconstituted wood panels, possibly increasing the ash content in UWW. Furthermore, UWW were sampled from a stack of wood displaced on the ground and with constant input and output of material, therefore, they could be contaminated with mineral soil material. The higher the ash content the higher is the wastage and maintenance of equipment (chippers, mills and crushers). Thus, the lower the ash content the lower is the cost of processing and disposal of UWW (Souza et al., 2009; Farage et al., 2013). 


\subsection{Higher heating value (HHV)}

The higher heating value and lower heating value showed no differences among the different treatments, for the same variable. The HHV ranged from $18.95 \mathrm{MJ} \mathrm{kg}^{-1}$ (T2) to $19.15 \mathrm{MJ}$ $\mathrm{kg}^{-1}$ (T4) with a difference of only $2 \%$ between these levels. The LHV showed a variation of 17.56 $\mathrm{MJ} \mathrm{kg}^{-1}$ (T3 treatment) to $17.79 \mathrm{MJ} \mathrm{kg}^{-1}$ (T4 treatment). These results indicate that there were no significant responses to heat energy when there was added Eucalyptus sp. to UWW.

\subsection{External mineral contaminants}

Treatment $\mathrm{T} 3$ showed the highest contamination level, followed by treatment $\mathrm{T} 2$, possibly due to contamination by substances adhered to UWW or coming from the contact with the ground in the stockyard, showing in values of $55.17 \%$ and $33.37 \%$, respectively (Figure 1).

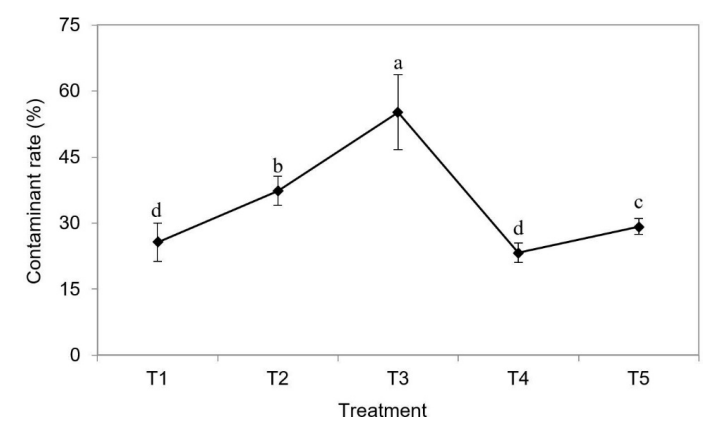

Figure 1. External mineral contamination content of the treatments. *Equal letters do not differ by the Scott-Knott test at $5 \%$ significance $(p>0.05)$.

The UWW, especially from the construction sector, may contain several minerals adhered to waste such as cements, mortars and other contaminants (Figure 1). In this case, even when in equal proportions of UWW and Eucalyptus sp. (treatment T3); there was a higher contamination rate, displaying no proportional behavior. This fact highlights the complexity of UWW and the necessity of studies to better understanding, treating and using these materials.

Beyond equipment wear, high content of minerals, inherent of material or from contamination, implies in greater accumulation at the site of combustion, requiring more frequent removals and also being abrasive and often leading to corrosion and fouling of equipment. Knowledge of this fact enables the planning of systems for their collection and disposal (Brand, 2010).

\subsection{Detection of heavy metals}

Among the heavy metal analyzed, described in Table 2, only mercury $(\mathrm{Hg})$ was lower than the detection limit (DL), which did not allow quantification.

Table 2. Heavy metal content.

\begin{tabular}{|c|c|c|c|c|c|c|}
\hline \multirow{2}{*}{$\begin{array}{c}\text { Treatment } \\
\text { Element }\end{array}$} & \multicolumn{3}{|c|}{ T1 } & \multicolumn{3}{|c|}{ T5 } \\
\hline & Wood & Ash & Variation (\%) & Wood & Ash & Variation (\%) \\
\hline Arsenic & 3.03 & 5.54 & 45.30 & 2.54 & 1.70 & -33.13 \\
\hline Chromium & 2.57 & 139.10 & 98.11 & 2.17 & 3.88 & 44.00 \\
\hline Copper & 6.61 & 244.61 & 97.23 & 4.85 & 41.31 & 88.21 \\
\hline Cadmium & 0.10 & 1.55 & 93.50 & 0.04 & 0.22 & 81.81 \\
\hline Zinc & 29.84 & 4300.24 & 99.34 & 20.10 & 70.97 & 71.67 \\
\hline Iron & 364.50 & 12408.33 & 97.12 & 127.60 & 2009.62 & 93.64 \\
\hline Lead & 11.49 & 353.55 & 96.70 & 0.85 & 0.85 & -2.31 \\
\hline Mercury & $<\mathrm{DL}$ & $<D L$ & - & $<\mathrm{DL}$ & $<\mathrm{DL}$ & - \\
\hline
\end{tabular}

Where: As = Arsenic $\left(\mathrm{mg} \mathrm{kg}^{-1}\right) ; \mathrm{Cr}=$ Chromium $\left(\mathrm{mg} \mathrm{kg}^{-1}\right) ; \mathrm{Cu}=\operatorname{Copper}\left(\mathrm{mg} \mathrm{kg}^{-1}\right) ; \mathrm{Cd}=$ Cadmium $\left(\mathrm{mg} \mathrm{kg}^{-1}\right) ; \mathrm{Zn}=\mathrm{Zinc}$ $\left(\mathrm{mg} \mathrm{kg}^{-1}\right) ; \mathrm{Fe}=\operatorname{Iron}\left(\mathrm{mg} \mathrm{kg}^{-1}\right) ; \mathrm{Pb}=\operatorname{Lead}\left(\mathrm{mg} \mathrm{kg}^{-1}\right) ; \mathrm{Hg}=$ Mercury $\left(\mathrm{mg} \mathrm{kg}^{-1}\right)$. DL = detection limit. 
The concentration of heavy metals was higher in T1 (UWW) than in T5 (Eucalyptus sp.), both in wood and ashes (Table 2). In the woods, Lead in T1 was the only element greater than the maximum established values, ranging from 7.0 to 10 for $\mathrm{As}, \mathrm{Cr}, \mathrm{Cu}, \mathrm{Cd}$ and $\mathrm{Pb}$ in wood and leaves of eucalyptus, according to Gonçalves et al. (1997) and Velasco Molina et al. (2006). Thus, the treatment containing only Eucalyptus sp. (T5) showed lower values and within the established limits, corroborating the idea that its addition to UWW can reduce the percentages of these elements. The concentrations of metals in Eucalyptus wood may be due to the fact that eucalyptus has a high absorption capacity of nutrients as well as heavy metals available in the soil (Soares et al., 2000). The higher content of elements analyzed was found in UWW (T1) and can be linked to the use of chemical solutions in surface finish and industrial preservatives such as $\mathrm{Ar}, \mathrm{Cr}, \mathrm{Cu}, \mathrm{Zn}, \mathrm{Hg}$ and $\mathrm{Pb}$ (Nilsson \& Jermer, 1999). Atkins \& Donovan (1996) also reported the presence of aluminum, titanium, iron and manganese in wood waste from urban origin. Also Silva (2006) and Vidal et al. (2015) argue that the higher levels of $\mathrm{Ar}, \mathrm{Cr}$ and $\mathrm{Cu}$, as presented in T1, can be derived from preservative solutions, traditionally used in the treatment of wood, in order to remain in contact with the soil, against xylophagous agents.

The heavy metals for T1 and T5 were higher in the ashes than in the wood, as observed by Hoffman et al. (1997), except for Arsenic in T5, which may be explained by his elemental boiling temperature of $614^{\circ} \mathrm{C}$. This temperature is lower than the temperature used to transform the wood into ashes $\left(750^{\circ} \mathrm{C}\right)$. This might be a hindrance in the use of this material, since heavy metal analysis in treatments for energy purposes are based on aspects that indicate the possibility of contamination by combustion; because emissions occur depending on the burning temperature and due to the different properties of the elements. Studies of quantification of the emissions may predict more specifically the potential of contamination by the UWW (Kovacs et al., 2016). For instance, the minimum temperature for incineration chamber of UWW is approximately $1000^{\circ} \mathrm{C}$ (Kovacs et al., 2016), with a recommendation by Brunner \& Brown (1988) that the gas emitted by the incinerator be filtered. This indicates that, overall, there was a concentration of these elements after combustion in ash formation.

The wood waste containing heavy metals are considered polluters (Hasan et al., 2011), negatively impacting the environment and human health in greater or lesser degree, depending on the concentration and use (Townsend et al., 2005; Kovacs et al., 2016). The higher values of the element concentrations in the ash show that care should be taken in discarding such materials without treatment, once the presence of heavy metals is in the materials, woods or ashes can contaminate the environment (soil, ground water, waterways, air, etc.), especially if they are deposited in the open sites or even in landfills and able to leach and/or solubilize (Krook et al., 2004, 2006; Kovacs et al., 2016; Hla et al., 2016).

\subsection{Multivariate analysis}

Table 3 shows that the first two principal components explain about $87 \%$ of the total variance of the data analyzed, and from these components, there were no major changes in the variances.

Table 3. Eigenvectors of the first two principal components.

\begin{tabular}{ccc} 
Variable & Component 1 & Component 2 \\
\hline Extractives content - EXT (\%) & 0.177 & 0.446 \\
Lignin content - LIG (\%) & 0.462 & 0.056 \\
Holocellulose content - HOL (\%) & -0.005 \\
Higher heating value - HHV (kcal kg-1) & -0.476 & -0.253 \\
Lower heating value - HLV (kcal kg-1) & 0.420 & -0.253 \\
Volatile matter content - VM (\%) & 0.420 & 0.487 \\
Fixed Carbon content - FC (\%) & 0.177 & -0.441 \\
Ash content - AS (\%) & -0.168 & 0.468 \\
Contamination Rate - CR (\%) & -0.024 & 0.130 \\
Eigenvalue & -0.335 & 3.40 \\
Variance (\%) & 4.39 & 37.80 \\
\end{tabular}


The first principal component basically represents the global performance index of feasibility analysis of the energy use of biomass (Protásio et al., 2013). The highest coefficients of the first principal component (Table 2) in module are related to holocellulose and lignin contents and also to the higher and lower heating values. It was noted that the higher heating value of the component (score), and the inverse was observed for ash content, contamination rate and fixed carbon content. As a strategy for energy generation these aspects unite the main features necessary for selecting UWW and Eucalyptus sp. compositions. The second principal component showed the contrast between the fixed carbon content and volatile matters, ash and extractives contents; in other words, it may reflect problems for the proposed energy use; since high values of this component (score) are associated with the generation of large amount of ash that leads to corrosion and fusion in equipment, and also lager elimination of gases, associated with high levels of volatile matters.

Figure 2 shows an ordering diagram of the variables and the scores of the first two principal components.

The values calculated of the first principal component score showed that the T4 treatment stands out due to its heating values (HHC and LHV) and lignin content, pointing to its energy use. The lowest scores of the second main component were observed for the T1 and $\mathrm{T} 2$, mainly because of the high ash contents (Figure 2). The T5 treatment had the highest score of the second principal component, because it's high holocellulose and fixed carbon contents. Treatment T3 showed a value close to zero due to the high contamination rate and high holocellulose content.

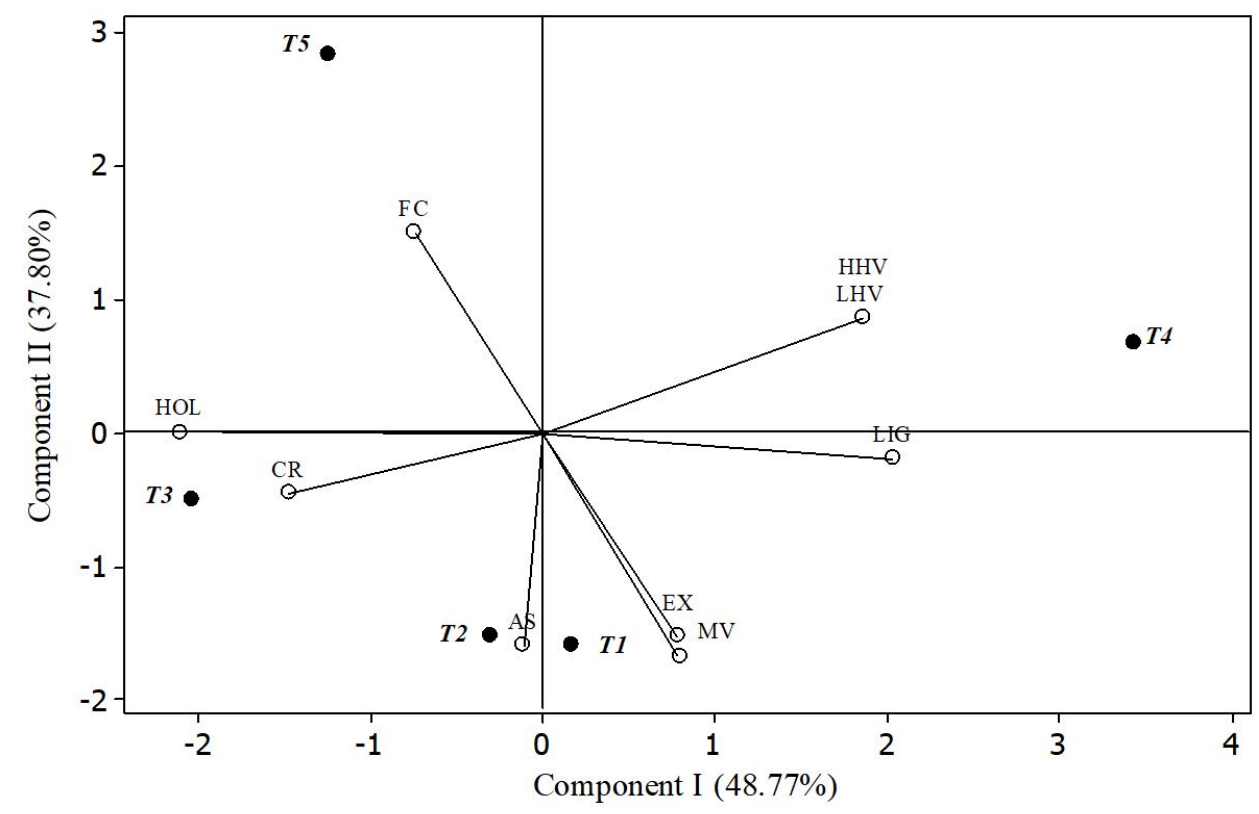

Figure 2. Ordination diagram of treatments considering the scores and eigenvectors of the principal components I and II. Where: EX = extractives content (\%); LIG = lignin content (\%); HOL = holocellulose content (\%); HHV = higher heating value $\left(\mathrm{MJ} \mathrm{kg}^{-1}\right)$; $\mathrm{LHV}=$ lower heating value (MJ); VM = volatile matter content (\%); FC = fixed carbon content (\%); $\mathrm{ASH}=$ ash content (\%); $\mathrm{CR}=$ contamination rate (\%).

\section{CONCLUSIONS}

The higher contamination rate was observed in the treatment with the same proportion of urban wood waste and Eucalyptus sp., demonstrating the difficulty of homogenizing this kind of material. The highest concentration of heavy metals was in the treatment consisting only of urban wood waste. Treatment T4 presented the best strategy to use urban wood waste, based on its lower ash content and lower contamination rate.

The principal component analysis was an effective tool in the evaluation and selection of treatment strategy. However, according to the ordination diagram T3, T4 and T5 formed 
distinct groups and T1 and T2 were grouped into a different group, since they had similar characteristics.

\section{ACKNOWLEDGMENTS}

We thank the Eco Verde Ambiental Ltda. for the cooperation and material donation. We also thank the Coordination for the Improvement of Higher Education Personnel (CAPES) and the Forestry Science Research Institute (IPEF) for the scholarships concessions.

\section{REFERENCES}

Aquino, F. W. B., Rodrigues, S., Nascimento, R. F., \& Casimiro, A. R. S. (2005). Phenolic compounds in imburana (Amburana cearensis) power extracts. European Food Research and Technology, 221(6), 739745. http://dx.doi.org/10.1007/s00217-005-0065-3.

Associação Brasileira de Normas Técnicas - ABNT. (1984). NBR 8633: carvão vegetal: determinação do poder calorífico (12 p.). Rio de Janeiro.

Associação Brasileira de Normas Técnicas - ABNT. (1986). NBR 8112: carvão vegetal: análise imediata (4 p.). Rio de Janeiro.

Associação Brasileira de Normas Técnicas - ABNT. (2004). NBR 10.007: amostragem de resíduos (9 p.). Rio de Janeiro.

Atkins, R. S., \& Donovan, C. T. (1996). EPA-600: wood products in the waste stream: characterization and combustion emissions. Technical report. Washington: U.S. Environmental Protection Agency.

Bouslamti, A., Irle, M. A., C, B., Salvador, V., Bondu, M., Hulo, S., \& Caron, B. (2012). Why simulate a sample of recycled wood? Maderas. Ciencia y Tecnología, 14(2), 145-153. http://dx.doi.org/10.4067/S0718-221X2012000200002.

Brand, M. A. (2010). Energia da biomassa florestal (114 p.). Rio de Janeiro: Interciência.

Brasil. Ministério do Meio Ambiente - MMA. (2009). Levantamento sobre a geração de resíduos provenientes da atividade madeireira e proposição de diretrizes para políticas, normas e condutas técnicas para promover o seu uso adequado (35 p.). Brasília. Retrieved in 2018, January 11, from http://www.mma.gov.br/estruturas/164/_publicacao/164_publicacao10012011032535

Brasil. (2017). Balanço Energético Nacional: relatório anual (296 p.). Brasília: Empresa de Pesquisa Energética, Ministério de Minas e Energia.

Brito, J. O., \& Ceribelli, U. L. (2012). Determinação de contaminantes sólidos não combustíveis na biomassa: procedimentos de análise: bioenergia e bioprodutos de base florestal. Piracicaba: USP/ESALQ. 1 p.

Brunner, C., \& Brown, C. (1988). Waste streams, technology, and state requirements. JAPCA, 38(10), 1297-1309. PMid:3236036. http://dx.doi.org/10.1080/08940630.1988.10467014.

Carvalho, W., Canilha, L., Ferraz, A., \& Milagres, A. M. F. (2009). Uma visão sobre a estrutura, composição e biodegradação da madeira. Química Nova, 32(8), 2191-2195. http://dx.doi.org/10.1590/S010040422009000800033.

Dias Júnior, A. F., Andrade, A. M., \& Costa Júnior, D. S. (2014). Caracterização de resíduos produzidos com resíduos agroflorestais. Pesquisa Florestal Brasileira, 34(79), 225-234. http://dx.doi.org/10.4336/2014.pfb.34.79.613.

Dias Júnior, A. F., Anuto, R. B., Andrade, C. R., Souza, N. D., Takeshita, S., Brito, J. O., \& Nolasco, A. M. (2017). Influence of eucalyptus wood addition to urban wood waste during combustion. Cerne, 23(4), 455-464. http://dx.doi.org/10.1590/01047760201723042337.

Farage, R. M. P., Rezende, A. A. P., Silva, C. M., Nunes, W. G., Carneiro, A. C. O., Vieira, D. B., \& Rodrigues, C. L. S. (2013). Avaliação do potencial de aproveitamento energético dos resíduos de madeira e derivados gerados em fábricas do polo moveleiro de Ubá - MG. Ciência Florestal, 23(1), 203-212. http://dx.doi.org/10.5902/198050988454.

Gonçalves, J. L. M., Van Raij, B., \& Gonçalves, J. C. (1997). Recomendação de adubação, fertilização e calagem de solos para o Estado de São Paulo. Campinas: IAC.

Hasan, A. R., Solo-Gabriele, H., \& Townsend, T. (2011). Online sorting of recovered wood waste by automated XRF-technology: part II. Sorting efficiencies. Waste Management, 31(4), 695-704. PMid:21194917. http://dx.doi.org/10.1016/j.wasman.2010.10.024.

$\mathrm{Hla}$, S. S., Lopes, R., \& Roberts, D. (2016). The $\mathrm{CO}_{2}$ gasification reactivity of chars produced from Australian municipal solid waste. Fuel, 185, 847-854. http://dx.doi.org/10.1016/j.fuel.2016.08.039. 
Hoffman, B. H., Tuomanen, B., Price 3rd, R., \& Beaulieu, H. J. (1997). Biological monitoring of employees with potential exposures to inorganic lead and cadmium at municipal solid waste resource recovery, or trash to energy, Facilities. Applied Occupational and Environmental Hygiene, 12(7), 471 479. http://dx.doi.org/10.1080/1047322X.1997.10390030.

Indústria Brasileira de Árvores - IBÁ. (2017). Relatório anual estatístico (80p.). São Paulo. Retrieved in 2018, January 11, from http://iba.org/images/shared/Biblioteca/IBA_RelatorioAnual2017.pdf

Iwakiri, S., Keinert Júnior, S., Mendes, L. M., Albuquerque, C. E. D., \& Latorraca, J. E. F. (2005). Painéis de madeira (196 p.). Curitiba: FUPEF.

Kovacs, H., Szemmelveisz, K., \& Koós, T. (2016). Theoretical and experimental metals flow calculations during biomass combustion. Fuel, 185, 524-531. http://dx.doi.org/10.1016/j.fuel.2016.08.007.

Krook, J., Martensson, A., \& Eklund, M. (2004). Metal contamination in recovered waste wood used as energy source in Sweden. Resources, Conservation and Recycling, 41(1), 1-14. http://dx.doi.org/10.1016/S0921-3449(03)00100-9.

Krook, J., Mârtensson, A., \& Eklund, M. (2006). Sources of heavy metal contamination in Swedish wood waste used for combustion. Waste Management, 26(2), 158-166. PMid:16198553. http://dx.doi.org/10.1016/j.wasman.2005.07.017.

Mingoti, A. S. (2005). Data analysis using multivariate statistical methods: an applied approach (1st ed., 297 p.). Belo Horizonte: Editora da UFMG.

Nilsson, K., \& Jermer, J. (1999). Inventory of the use of preservative-treated wood and wood preservatives in Sweden 1900-1997. In Proceedings of the Annual Meeting of the International Research Group on Wood Preservation (IRG/WP 99-50137). Stockholm: IRG.

Pecho, R., Ananias, R. A., Ballerini, A., \& Cloutier, A. (2004). Influencia de la madera juvenil de pino radiata sobre las propiedades mecánicas de tableros osb. Maderas. Ciencia y Tecnología, 6(1), 45-59. http://dx.doi.org/10.4067/S0718-221X2004000100004.

Protásio, T. P., Bufalino, L., Guimarães Junior, M., Tonoli, G. H. D., \& Trugilho, P. F. (2013). Técnicas multivariadas aplicadas na avaliação de resíduos lignocelulósicos para bioenergia. Ciência Florestal, 23(4), 771-781. http://dx.doi.org/10.5902/1980509812361.

Quirino, W. F., Vale, A. T., Andrade, A. P. A., Abreu, V. L. S., \& Azevedo, A. C. S. A. (2004). Poder calorífico da madeira e de resíduos de madeira. Biomassa \& Bioenergia, 1(2), 173-182.

Reijnders, L. (2000). A normative strategy for sustainable resource choice and recycling. Resources, Conservation and Recycling, 28(2), 121-133. http://dx.doi.org/10.1016/S0921-3449(99)00037-3.

Reis, L. B. (2015). Electricity generating (1st ed., 461 p.). Barueri: Manole.

Rowell, R. M., Han, J. S., \& Rowell, J. S. (2000). Characterization and factors affecting fiber properties. In E. Frollini, A. Leão \& L. H. C. Mattoso (Eds.), Natural polymers and agrofibers composites (133 p.). São Carlos: IQSC.

Scotland, R. (2004). Woodwaste arisings in scotland: assessment of available data on scottish woodwaste arisings (3rd ed., 23 p.). Glasgow: Drumond House.

Sgarbossa, A., Costa, C., Menesatti, P., Antonucci, F., Pallottino, F., Zanetti, M., Grigolato, S., \& Cavalli, R. (2015). A multivariate SIMCA index as discriminant in wood pellet quality assessment. Renewable Energy, 76, 258-263. http://dx.doi.org/10.1016/j.renene.2014.11.041.

Silva, J. C. (2006). Madeira preservada: os impactos ambientais. Revista da Madeira, 100(1).

Soares, C. R. F. S., Siqueira, J. O., Carvalho, J. G., Moreira, F. M. S., \& Grazziotti, P. H. (2000). Crescimento e nutrição mineral de Eucalyptus maculata e Eucalyptus urophylla em solução nutritiva com concentração crescente de cobre. Revista Brasileira de Fisiologia Vegetal, 12(3), 213-225. http://dx.doi.org/10.1590/S0103-31312000000300005.

Souza, S. S., Sanatos, P. O., Varejão, M. J. C., \& Nascimento, C. C. (2009). Detection of ash and silica content into lignocellulosic materials. In Reunião Anual da Sociedade Brasileira de Progresso da Ciência (1 p.). São Paulo: SBPC.

Strandberg, A., Holmgren, P., \& Broström, M. (2017). Predicting fuel properties of biomass using thermogravimetry and multivariate analysis. Fuel Processing Technology, 156, 107-112. http://dx.doi.org/10.1016/j.fuproc.2016.10.021.

Technical Association of the Pulp and Paper Industry - TAPPI. (1975). TAPPI T-12 05-75: industry preparation of wood for chemical analysis (Including procedures for removal of extractives an determination of moisture content) (21 p.). Atlanta.

Technical Association of the Pulp and Paper Industry - TAPPI. (1974). TAPPI 222 05-74: industry lignin in wood (12 p.). Atlanta. 
Townsend, T., Dubey, B., Tolaymat, T., \& Solo-Gabriele, H. (2005). Preservative leaching from weathered CCA treated wood. Journal of Environmental Management, 75(2), 105-113. PMid:15763153. http://dx.doi.org/10.1016/j.jenvman.2004.11.009.

U.S. Environmental Protection Agency - EPA. (2000). EPA SW 846 6010C: microwave assisted acid digestion of sediments sludge, soils, and oils: test methods for evaluating solid waste (30 p.). Washington.

U.S. Environmental Protection Agency - EPA. (2007). EPA SW 846 3051A: Test methods for evaluating solid waste (30 p.). Washington.

Velasco Molina, M., Mattiazzo, M. E., Andrade, C. A., \& Poggiani, F. (2006). Nitrogênio e metais pesados no solo e em árvores de eucalipto decorrentes da aplicação de biossólido em plantio florestal. Scientia Forestalis, 71, 25-35.

Vidal, J. M., Evangelista, W. V., Silva, J. C., \& Jankowsky, I. (2015). Preservação de madeira no Brasil: histórico, cenário atual e tendências. Ciência Florestal, 25(1), 257-271. http://dx.doi.org/10.5902/1980509817484.

Wiecheteck, M. (2009). Aproveitamento de resíduos e subprodutos florestais, alternativas tecnológicas e propostas de políticas ao uso de resíduos florestais para fins energéticos (Sumário Executivo). Brasília: Ministério do Meio Ambiente. Retrieved in 2018, January 11, from http://www.mma.gov.br/estruturas/164/_publicacao/164_publicacao10012011033501.pdf

Yamamoto, M., lakovlev, M., Bankar, S., Tunc, M. S., \& Van Heiningen, A. (2014). Enzymatic hydrolysis of hardwood and softwood harvest residue fibers released by sulfur dioxide-ethanol-water fractionation. Bioresource Technology, 167, 530-538. PMid:25022728. http://dx.doi.org/10.1016/j.biortech.2014.06.054.

Authors' contributions: AFDJ: conceptualization, funding acquisition, supervision, writing, data analysis; HA: funding acquisition, methodology, writing, data analysis; AQL: funding acquisition, formal analysis, methodology; CRA: funding acquisition, formal analysis, methodology; JOB: supervision, writing, funding acquisition; data curation; GBJ: supervision, writing, funding acquisition; data curation. 